\title{
Nitrogen Converters in Various Landfill Leachates
}

\author{
Deniz Akgul ${ }^{1}$, Burak Yuzer², Kozet Yapsakli' ${ }^{1}$, Bulent Mertoglu ${ }^{3 *}$ \\ ${ }^{1}$ Department of Environmental Engineering, Marmara University, Istanbul, Turkey \\ ${ }^{2}$ Department of Environmental Engineering, Istanbul University, Istanbul, Turkey \\ ${ }^{3}$ Department of Bioengineering, Marmara University, Istanbul, Turkey
}

Received: 17 September 2017

Accepted: 2 November 2017

\begin{abstract}
Nitrogen has significant adverse effects on the environment and leads to operational failure in biological treatment units. Therefore, it is necessary to investigate and implement new nitrogen conversion pathways in order to expand alternatives for in-situ/ex-situ leachate treatment systems. In this study, microbial species responsible for nitrogen conversion were quantitatively investigated based on both phylogenetic and functional gene markers using real-time PCR in nine different leachate samples in Turkey. Real-time PCR studies revealed that landfill leachate harbored diverse nitrogen-converting microbial communities that include ammonia-oxidizing bacteria, nitrite-oxidizing bacteria, anammox bacteria, and ammonia-oxidizing archaea (AOA). Nitrosomonas and Nitrospira species were found to be the dominant ammonia- and nitrite-oxidizing bacteria, respectively. In contrast to the estimates, on average Nitrospira species were detected as 5 times more abundant than ammonia-oxidizing bacteria species. The presence of anammox and AOA revealed that partial nitrogen removal may occur inside landfills.
\end{abstract}

Keywords: ammonia-oxidizing archaea, anammox, landfill, leachate, nitrogen converter

\section{Introduction}

Landfilling is an effective solid waste disposal method in developing countries. Although it is a relatively cheap and simple way to eliminate waste, the treatment of leachate with high pollutant concentrations is a serious issue. Nitrogen elimination is one of the main problems of leachate treatment, especially in Turkey. High nitrogen concentrations of up to $5,000 \mathrm{mg} \mathrm{L}^{-1}$ cause operational failure in anaerobic and aerobic biological treatment units [1]. Treating and managing leachate has been an ongoing challenge for landfill designers all over the world. Different factors, such as landfill age,

*e-mail: bulent.mertoglu@marmara.edu.tr meteorological factors, and seasonal variations may influence the organic matter and nitrogen concentrations in landfill leachate. Organic matter and nitrogen concentrations significantly vary, showing highest concentrations in summer because of evaporation, and lower concentrations in winter because of dilution with precipitation. Apart from this variation, organic matter decomposes while nitrogen concentration increases over time in the landfill. In order to design and operate a leachate treatment plant efficiently, scientists have to analyze seasonal and long-term variations in landfill leachate.

The removal of nitrogen compounds in leachate is of high priority to eliminate its inhibitory effects on treatment processes. In order to remove nitrogen from leachate, several ex-situ technologies have been 
developed such as biological processes (nitrification/ denitrification or Sharon/Anammox) [2-3], air stripping [4], struvite precipitation [5], adsorption by activated carbon [6], zeolite [7], and composite materials [8]. In recent years, in-situ removal of nitrogen has become an attractive alternative technology in bioreactor landfill studies [9-11]. Researchers have studied in-situ (forced bottom aeration-recirculation) or partially in-situ denitrification (ex-situ nitrification-recirculation) at the laboratory and full-scale studies [11-13]. Since the ex-situ removal of ammonia from high-strength leachate can be difficult and costly [11], in-situ removal technologies are being investigated. However, the mechanisms of in-situ nitrogen removal in an aerated municipal solid waste (MSW) bioreactor are not yet understood. Hao [14] observed that the amount of ammonium consumed is much higher than that of the nitrite and nitrate produced in an MSW bioreactor. High temperature and $\mathrm{pH}$ within the landfill sites may favor the formation of free ammonia, hence air stripping may be the dominant pathway of ammonia removal.

New developments related to microbial tools have explored new pathways and players in the global nitrogen cycle [15-18]. The recent discovery of new players, anoxic ammonium oxidizer (anammox) has upended our prejudice that nitrogen can only be eliminated in the presence of oxygen. Anammox bacteria were first discovered in a denitrifying pilot plant reactor in Delft. The process involves the oxidation of ammonium nitrogen to nitrogen gas, with nitrite nitrogen as the electron acceptor under an anoxic environment [17]. After the discovery of anammox, AOA has also been identified as playing a key role in the global nitrogen cycle. Moreover, some scientists have indicated that the abundance of ammonia-oxidizing archaea is more numerically dominant than ammoniaoxidizing bacteria in some environments [15-16]. In recent years, researchers have shown that members of the nitrite-oxidizer genus Nitrospira are capable of complete nitrification and grow by the oxidation of ammonia to nitrate in a single organism [18]. Therefore, these new mechanisms in landfill sites and the microbial communities responsible for these processes have to be exposed in order to highlight alternative in/ex-situ leachate treatment systems.

Determining new players in the nitrogen cycle is also important in terms of bioaugmentation practices. It has been reported that bioaugmentation can be used in in-situ leachate treatment, which may enhance ammonia removal - especially at high concentrations [19]. By understanding the nitrogen removal mechanisms in landfills, the effectiveness of bioaugmentation can be increased.

Microbial population monitoring with the use of molecular tools can account for the nitrogen removal mechanisms in landfills. Until now, however, only limited data have been published on in-situ removal of ammonia in bioreactor landfills by using molecular microbiological studies $[10,20]$. The presence of sensitive nitrogen converters $\mathrm{AOB}, \mathrm{NOB}, \mathrm{AOA}$, and anammox bacteria were investigated in landfill leachate samples taken directly from 8 different cities in Turkey. To the best of our knowledge, this would be the first study to evaluate microorganisms taking part in the nitrogen cycle in samples taken from a landfill.

\section{Material and Methods}

\section{Landfill Sites}

Leachate samples from several solid waste landfills in Turkey (Istanbul Komurcuoda and Odayeri, Ankara, Antalya, Bursa, Gaziantep, Samsun and Trabzon) were collected to investigate the abundance of microorganisms taking part in the nitrogen cycle. In addition to molecular microbiological analysis, physical and chemical characterizations of these samples were conducted in leachate samples. These cities are located in different regions of Turkey and exhibit different climatic conditions, populations, and regional properties. Additionally, the composition of solid wastes and landfill structures are different.

Odayeri and Kömürcüoda sanitary landfills are located in the European and Asian sides of Istanbul, respectively. Although leachate samples were taken from both active and closed sites in Odayeri Landfill, Kömürcüoda leachate sample was taken from the active section of the landfill. Bursa Hamitler Sanitary Landfill is located in the southern Marmara Region, which consists of five different storage areas. Although the landfill site is 15 years old, the leachate sample was taken from the equalization tank that combines active and old landfill leachate. Ankara Sanitary Landfill is composed of 2 storage areas where municipal solid wastes and salt industry wastes are stored separately. The leachate sample was taken from the municipal waste storage area. Ankara is a new landfill and leachate is not treated; leachate is recirculated back to the landfill body. The sanitary landfill site of Antalya has been accepting solid waste since 2003 and it is composed of 7 storage areas. The leachate sample was taken from the active storage area. Gaziantep is the largest city in Turkey's southeastern Anatolia Region. Gaziantep sanitary landfill site has been accepting solid waste since 1996. Since it is composed of only one storage cell, the landfill site is still active. Leachate is recirculated to the landfill body and an excess amount is transported to the municipal wastewater treatment plant. Trabzon and Samsun are cities on the Black Sea coast of northeastern and northern Turkey and have been accepting solid waste since 2007 and 2008, respectively.

\section{Physical and Chemical Properties of Leachate Samples}

Leachate samples were kept at $4^{\circ} \mathrm{C}$ until analyzed in order to prevent changes in the physical and chemical 
Table 1. Measurement methods for the analyses conducted to characterize leachate samples.

\begin{tabular}{|c|c|}
\hline Analyses & Measurement Method \\
\hline $\mathrm{pH}$ & $4500-\mathrm{H}^{+}$B. Electrometric Method \\
\hline Total Alkalinity & 2320 B. Titration Method \\
\hline Chemical Oxygen Demand & 5220 D. Closed Reflux Colorimetric Method \\
\hline Biochemical Oxygen Demand & 5210 D. Respirometric Method \\
\hline Ammonium Nitrogen & 4500 C. Titrimetric Method \\
\hline Total Kjeldahl Nitrogen & $4500-\mathrm{N}_{\text {org }}$ Nitrogen- Semi Micro-Kjeldahl Method \\
\hline Total Solids & 2540 B. Total Solids Dried at $103-105^{\circ} \mathrm{C}$ \\
\hline Total Suspended Solids & 2540 D. Total Suspended Solids Dried at $103-105^{\circ} \mathrm{C}$ \\
\hline Volatile Suspended Solids & 2540 E. Fixed and Volatile Solids Ignited at $550^{\circ} \mathrm{C}$ \\
\hline Total Organic Carbon & 5310 B. High Temperature Combustion Method \\
\hline
\end{tabular}

parameters. The analytical methods were conducted according to [2]. Experimental analyses and methods of measurement are listed in Table 1.

\section{Molecular Microbiological Studies}

For molecular analysis, a single sample was analyzed for each landfill area. Microorganisms in landfill leachate samples were harvested by centrifuging at 7,000 rpm for $30 \mathrm{~min}$. Concentrated samples were stored in a freezer at $-20^{\circ} \mathrm{C}$ prior to molecular analyses. Nucleic acid extraction was performed according to the protocol provided with the FastDNA SPIN kit (Q-BIOgene) with minor modifications [21]. Final DNA concentrations were quantified according to the protocol provided with the Quant-iT PicoGreen dsDNA reagent kit (molecular probes) with minor modifications. The PicoGreen reagent concentrated solution in DMSO was prepared by 80 -fold dilution (instead of 200 -fold) in 1x TE buffer (10 mM Tris-HCl, $1 \mathrm{mM}$ EDTA, pH7.5). Extracted DNA samples diluted in $10 \mu \mathrm{l}$ of TE buffer were mixed with $10 \mu$ PicoGreen working solution to reach a final volume. Measurements were calculated as a result of triplicate analysis.

Real-time PCR was performed using the LightCycler Instrument (Roche, Germany) with the FastStart DNA Master SYBR Green I kit (Roche) following the manufacturer's protocol. The quantitative PCR program included an initial denaturation for $10 \mathrm{~min}$ at $95^{\circ} \mathrm{C}$, followed by 40 cycles of denaturation at $95^{\circ} \mathrm{C}$ for $10 \mathrm{~s}$, annealing for $10 \mathrm{~s}$ at $57^{\circ} \mathrm{C}$, and extension for $45 \mathrm{~s}$ at $72^{\circ} \mathrm{C}$. The temperature transition rate was $20^{\circ} \mathrm{C} \mathrm{s}^{-1}$ at all steps. SYBR Green real-time PCR reaction mixture consisted of $2.0 \mu \mathrm{L}, 10 \mathrm{x}$ Mastermix; $2.0 \mu \mathrm{L}, 25 \mathrm{mM}$ $\mathrm{MgCl}_{2} ; 1.25 \mu \mathrm{M}$ of each primer; $2 \mu \mathrm{L}$, template DNA (with a dilution factor of 10 to prevent PCR inhibition), and up to $20 \mu \mathrm{L}$ of double distilled pure water. Six sets of primers - 341f-907r for partial 16S rRNA bacterial gene, amoA1F-amoA2R for amoA ammonia oxidizing bacterial gene, FGPS872-FGPS1269 for 16S
rRNA Nitrobacter sp., NSR1113F-NSR1264R for 16S rRNA Nitrospira sp., Arch-amoAF-Arch-amoAR for amoA ammonia oxidizing archaeal gene, and PLA46fAmx667r for anammox bacteria - were used to amplify a target sequence from 9 different leachate samples [22]. Potassium chloride with a final concentration of $18 \mathrm{mM}$ was added to real-time PCR mixtures to provide the correct ionic strength targeting the 16S rRNA gene of Nitrobacter [23]. In all experiments, appropriate negative controls containing no template DNA were subjected to the same procedure to exclude or detect any possible contamination. Real-time PCR results were evaluated using the LightCycler data analysis software (version 4.0). Melting curve analysis was performed with a programmed temperature transition rate of $0.1^{\circ} \mathrm{C} \mathrm{s}^{-1}$ from $65^{\circ} \mathrm{C}$ to $95^{\circ} \mathrm{C}$ to confirm specificity of amplification and minimize nonspecific amplification and rule out primer-dimer generation.

Real-time PCR quantification is accomplished by constructing an external DNA standard curve using a series of 10-fold dilutions of known copy numbers of target genes. PCR fragments excised from agarose gel $(0.8 \%)$ were purified using a MinElute Gel Extraction Kit (Qiagen). Quant-iT PicoGreen dsDNA reagents and kit were used to determine the concentration of DNA [24]. $\mathrm{R}^{2}$ values were always greater than 0.99 for the entire standard curves. Quantification is then done in the unknown sample by calculating from the standard curve.

\section{Results and Discussion}

\section{Leachate Characterization}

Physico-chemical analyses have shown that great variations in terms of both composition and characteristics existed among the leachate samples. Physico-chemical characterization of leachate samples is depicted in Table 2. 
Table 2. Physical and chemical characterisation of samples.

\begin{tabular}{|c|c|c|c|c|c|c|c|c|c|}
\hline & Antalya & Ankara & Bursa & Gaziantep & $\begin{array}{c}\text { İstanbul } \\
\text { Odayeri-1 }\end{array}$ & $\begin{array}{c}\text { İstanbul } \\
\text { Odayeri-2 }\end{array}$ & $\begin{array}{c}\text { İstanbul } \\
\text { Kömürcüoda }\end{array}$ & Samsun & Trabzon \\
\hline $\mathrm{pH}$ & 6.5 & 8.6 & 7.9 & 8.2 & 7.4 & 8.2 & 7.7 & 7.4 & 7.5 \\
\hline $\begin{array}{c}\text { Conductivity, } \\
\mu \mathrm{S} / \mathrm{cm}\end{array}$ & 33800 & 23500 & 30300 & 38500 & 34200 & 34900 & 27700 & 17800 & 12880 \\
\hline $\begin{array}{l}\text { Total Alkalinity, } \\
\mathrm{mg} / \mathrm{L} \text { as } \mathrm{CaCO}_{3}\end{array}$ & 14850 & 3000 & 12400 & 15500 & 13950 & 14850 & 10100 & 10500 & 4800 \\
\hline $\begin{array}{c}\text { Total Suspended } \\
\text { Solids, mg/L }\end{array}$ & 4800 & 633 & 138 & 1810 & 2840 & 529 & 3440 & 2120 & 1220 \\
\hline $\begin{array}{c}\text { Volatile } \\
\text { Suspended Solids, } \\
\mathrm{mg} / \mathrm{L}\end{array}$ & 3360 & 340 & 135 & 1190 & 1160 & 329 & 2100 & 1150 & 760 \\
\hline $\begin{array}{c}\text { Total Solids, } \\
\mathrm{mg} / \mathrm{L}\end{array}$ & 47056 & 16840 & 15200 & 28500 & 34496 & 18128 & 24200 & 24410 & 8590 \\
\hline $\begin{array}{l}\text { Chemical Oxygen } \\
\text { Demand, mg/L }\end{array}$ & 69018 & 1480 & 4048 & 17846 & 40600 & 11289 & 28716 & 28554 & 6665 \\
\hline $\begin{array}{l}5 \text { Day-Biochem- } \\
\text { ical Oxygen } \\
\text { Demand, mg/ L }\end{array}$ & 37394 & 140 & 1380 & 9913 & 27000 & 4500 & 17230 & 15611 & 3415 \\
\hline $\begin{array}{l}\text { Total Organic } \\
\text { Carbon, mg/ L }\end{array}$ & 22094 & 623 & 1120 & 8678 & 13612 & 4575 & 10774 & 8466 & 3031 \\
\hline $\begin{array}{c}\text { Total Kjeldahl } \\
\text { Nitrogen, mg N/L }\end{array}$ & 3642 & 163 & 2920 & 3900 & 3445 & 4230 & 3200 & 2836 & 1038 \\
\hline $\begin{array}{c}\text { Ammonia } \\
\text { nitrogen, } \mathrm{mg} \mathrm{N} / \mathrm{L}\end{array}$ & 2220 & 91 & 2280 & 3550 & 2740 & 3460 & 2560 & 2400 & 920 \\
\hline $\mathrm{BOD}_{5} / \mathrm{COD}$ & 0.54 & 0.09 & 0.34 & 0.56 & 0.67 & 0.40 & 0.60 & 0.55 & 0.51 \\
\hline
\end{tabular}

In general, the stabilization phase of landfill is mostly determined by considering $\mathrm{BOD}_{5}, \mathrm{COD}, \mathrm{pH}$, and $\mathrm{BOD}_{5} / \mathrm{COD}$ ratio. In literature, $\mathrm{COD}$ and $\mathrm{BOD}_{5}$ in acid phase leachates were mostly reported to be between 6,000 to $60,000 \mathrm{mg} \mathrm{L}^{-1}$ and 4,000 to $40,000 \mathrm{mg} \mathrm{L}^{-1}$, respectively [25]. These parameters dramatically change through the progression of waste stabilization [26]. In previous studies, $\mathrm{BOD}_{5} / \mathrm{COD}$ ratio in acid phase was shown to vary between 0.4 [27] and 0.6 [1, 28], with such high ratios implying high biodegradability. However, the $\mathrm{BOD}_{5} / \mathrm{COD}$ ratio can decrease even down to 0.1 [27] in response to the aging of the landfill. Another indicator of the stabilization phase, $\mathrm{pH}$, could vary between 4.5 and 7.5 in the case of acid phase, and 7.5 and 9.0 in the case of methanogenic phase [25]. In light of the above information, it is concluded that Antalya, Gaziantep, İstanbul Odayeri-1, İstanbul Kömürcüoda, and Samsun landfills are in acid phase. Bursa Landfill seems to be in methanogenic phase with low organic content since the sample was taken from the equalization tank, which combines the old and young landfill lots. Because Trabzon Landfill is located in the rainiest region in Turkey, the pollutant loads were mostly found to be low. However, $\mathrm{BOD}_{5} / \mathrm{COD}$ ratio and $\mathrm{pH}$ of leachate samples indicated that Trabzon Landfill is in the acid-intermediate phase. İstanbul Odayeri-2 Landfill is in the intermediate-methanogenic phase with high $\mathrm{pH}$ and relatively low organic content. During the time of sampling, Ankara Landfill was a newly constructed landfill and a small amount of produced leachate was transferred back to the landfill storage lot. Therefore, the chemical characteristics suit neither the acid nor methanogenic phases. At least $2,000 \mathrm{mg} \mathrm{L}^{-1}$ of $\mathrm{TKN}$ concentrations were observed in all landfill sites except Ankara and Trabzon. It is interesting to note that in Gaziantep and Istanbul, TKN concentrations exceed 4,000 $\mathrm{mg} \mathrm{L}^{-1}$, and such high concentrations are seldom found in literature [29-30]. High ammonia concentrations are expected to occur in MSW landfills as a result of nitrogen-rich food waste or climatic conditions. High nitrogen concentrations and their difficulty of treatment at high efficiencies take nitrogen to focus interest in leachate management. Therefore, it is necessary to find economical solutions for the in-situ treatment of nitrogen in landfill leachate. In order to find such solutions, it is essential that all possible microbial-driven processes/mechanisms taking part in the nitrogen cycle be unravelled, and at the same time, abundance and diversity of the players in the nitrogen cycle be determined in leachate.

\section{Identifying Nitrogen Converters}

From the start-up to the stabilization of the landfill, various microorganisms play active roles in the system 
Table 3. Quantitative analyses of 16S rRNA, amoA AOB, 16S rRNA Nitrobacter, 16S rRNA Nitrospira, amoA AOA, and 16S rRNA anammox bacteria by real-time PCR.

\begin{tabular}{|c|c|c|c|c|c|c|}
\hline \multirow{2}{*}{ Samples } & \multicolumn{6}{|c|}{ Gene copy number } \\
\cline { 2 - 7 } & $16 \mathrm{~S}$ rRNA & amoA AOB & Nitrobacter & Nitrospira & amoA AOA & Anammox \\
\hline Antalya & $2.88 \times 10^{7}$ & $9.44 \times 10^{4}$ & $1.93 \times 10^{3}$ & $2.78 \times 10^{5}$ & $2.64 \times 10^{3}$ & $2.36 \times 10^{4}$ \\
\hline Ankara & $1.03 \times 10^{7}$ & $6.98 \times 10^{4}$ & $8.24 \times 10^{2}$ & $1.88 \times 10^{5}$ & $2.05 \times 10^{3}$ & $5.08 \times 10^{3}$ \\
\hline Bursa & $3.18 \times 10^{7}$ & $2.31 \times 10^{5}$ & $3.52 \times 10^{3}$ & $7.97 \times 10^{5}$ & $2.83 \times 10^{3}$ & $2.13 \times 10^{4}$ \\
\hline Gaziantep & $6.16 \times 10^{6}$ & $3.68 \times 10^{4}$ & $4.01 \times 10^{2}$ & $8.79 \times 10^{4}$ & $5.74 \times 10^{2}$ & $7.66 \times 10^{3}$ \\
\hline İstanbul Odayeri-1 & $5.00 \times 10^{7}$ & $2.70 \times 10^{5}$ & $1.18 \times 10^{4}$ & $1.15 \times 10^{6}$ & $8.06 \times 10^{3}$ & $1.88 \times 10^{4}$ \\
\hline İstanbul Odayeri-2 & $1.39 \times 10^{7}$ & $1.02 \times 10^{5}$ & $9.85 \times 10^{3}$ & $1.94 \times 10^{5}$ & $2.83 \times 10^{3}$ & $7.46 \times 10^{3}$ \\
\hline İstanbul Kömürcüoda & $6.03 \times 10^{7}$ & $3.38 \times 10^{5}$ & $5.63 \times 10^{3}$ & $9.57 \times 10^{5}$ & $7.45 \times 10^{3}$ & $5.14 \times 10^{4}$ \\
\hline Samsun & $6.28 \times 10^{6}$ & $2.15 \times 10^{4}$ & $2.82 \times 10^{2}$ & $4.60 \times 10^{4}$ & $4.03 \times 10^{2}$ & $3.68 \times 10^{3}$ \\
\hline Trabzon & $2.11 \times 10^{7}$ & $1.15 \times 10^{5}$ & $1.87 \times 10^{3}$ & $2.89 \times 10^{5}$ & $2.47 \times 10^{3}$ & $6.14 \times 10^{3}$ \\
\hline
\end{tabular}

while decomposing organic matter in anaerobic conditions. The composition of biogas and leachate differs due to the change of microbial activities during the landfill stabilization period. Molecular microbiological techniques have largely contributed to our understanding of the diversity and distribution of these microorganisms in the environment. Therefore, in recent years the operational criteria of landfills are investigated not only through leachate characterization and gas composition but also with the description of the diversity of microorganisms in the system [10, 31-32].

Target gene copy numbers and the fraction of nitrogen-converting organisms among whole microorganisms belonging to 9 leachate samples were estimated by copy numbers of corresponding genes using real-time PCR and are shown in Tables 3 and 4, respectively. Copy numbers and fractions for all samples analysed under the current study were calculated using the following assumption: bacterial cell has an average of 3.6 ribosomal operon copies per cell, amo $A$ gene has 2 ribosomal operon copies per cell, and Nitrospira, AOA, and anammox cells have an average of one ribosomal operon copies per cell [33]. Total bacterial numbers were enumerated using $16 \mathrm{~S}$ rRNA gene copy numbers as proxy. Among the 9 leachate samples that were studied, the $16 \mathrm{~S}$ rRNA copy numbers consistently ranged from $6.16 \times 10^{6}$ (for Gaziantep) to $6.03 \times 10^{7}$ (for İstanbul Kömürcüoda) per $\mu \mathrm{L}$ of extracted DNA. Microorganisms responsible for nitrification were quantified using amoA gene in ammonia-oxidizing bacteria (AOB) and amoA gene in archaea (AOA). The results showed that the bacterial amoA copy numbers ranged from $2.15 \times 10^{4}$ (Samsun) to $3.92 \times 10^{5}$ (İstanbul Kömürcüoda) per $\mu \mathrm{L}$ of extracted DNA, which approximately outnumbered nearly 30 times more with respect to archaeal amoA. Low abundances of archaeal amoA can be attributed to high ammonium nitrogen concentrations in all leachate samples analyzed. There is a general agreement among researchers that archaeal amoA gene abundance correlated negatively to the

Table 4. Fraction of microorganisms participating in nitrogen conversion in different landfills with respect to bacterial 16S rRNA gene

\begin{tabular}{|c|c|c|c|c|c|}
\hline Samples & $\begin{array}{c}\text { amoA AOB/ } \\
16 \mathrm{~S} \text { rRNA }\end{array}$ & $\begin{array}{c}\text { Nitrobacter/ } \\
16 \mathrm{~S} \text { rRNA }\end{array}$ & $\begin{array}{c}\text { Nitrospira/ } \\
16 \mathrm{~S} \text { rRNA }\end{array}$ & $\begin{array}{c}\text { amoA AOA/ } \\
16 \mathrm{~S} \text { rRA }\end{array}$ & $\begin{array}{c}\text { Anammox/ } \\
16 \mathrm{~S} \text { rRNA }\end{array}$ \\
\hline Antalya & $0.59 \%$ & $0.02 \%$ & $3.47 \%$ & $0.03 \%$ & $0.29 \%$ \\
\hline Ankara & $1.22 \%$ & $0.03 \%$ & $6.59 \%$ & $0.07 \%$ & $0.18 \%$ \\
\hline Bursa & $1.31 \%$ & $0.04 \%$ & $9.02 \%$ & $0.03 \%$ & $0.24 \%$ \\
\hline Gaziantep & $1.07 \%$ & $0.02 \%$ & $5.14 \%$ & $0.03 \%$ & $0.45 \%$ \\
\hline İstanbul Odayeri-1 & $0.97 \%$ & $0.09 \%$ & $8.28 \%$ & $0.06 \%$ & $0.14 \%$ \\
\hline İstanbul Odayeri-2 & $1.32 \%$ & $0.26 \%$ & $5.04 \%$ & $0.07 \%$ & $0.19 \%$ \\
\hline İstanbul Kömürcüoda & $1.01 \%$ & $0.03 \%$ & $5.71 \%$ & $0.04 \%$ & $0.31 \%$ \\
\hline Samsun & $0.62 \%$ & $0.02 \%$ & $2.64 \%$ & $0.02 \%$ & $0.21 \%$ \\
\hline Trabzon & $0.98 \%$ & $0.03 \%$ & $4.94 \%$ & $0.04 \%$ & $0.10 \%$ \\
\hline
\end{tabular}


ammonium concentrations in natural and engineering systems. This is mainly because of the lower affinity of AOA toward nitrogen compared to AOB species. The AOA half-saturation constant $\left(\mathrm{K}_{\mathrm{s}}\right)$ for ammonia is reported to be one to three orders of magnitude lower than that of AOB species by various researchers [3437]. This means that only at low ammonium nitrogen levels can AOA be dominant, which explains the low abundances of AOA in all analyzed samples.

The copy numbers of the $16 \mathrm{~S}$ rRNA gene of anammox bacteria in 9 leachate samples ranged from $3.68 \times 10^{3}$ (Samsun) to $5.14 \times 10^{4}$ (İstanbul Kömürcüoda) per $\mu \mathrm{L}$ of extracted DNA (Table 3 ). The fraction of anammox bacteria in analysed leachate samples varied between $0.10 \%$ (Trabzon) and $0.45 \%$ (Gaziantep; Table 4). The low fraction of anammox bacteria may suggest that they are not the main players in any of the studied landfills. However, the detection of the 16S rRNA gene of anammox bacteria indicates that although in low abundances, a fraction of anammox bacteria could still survive despite the presence of such high organic matter concentrations.

The percentage of amoA gene from ammoniumoxidizing bacteria in the total amount of microorganisms ranged from $0.59 \%$ to $1.32 \%$ in samples. The presence of the amoA gene in leachate samples can be taken as a measure of the genetic potential for nitrification [38]. In this study, there was a correlation between the fraction of $\mathrm{AOB}$ among all microorganisms and $\mathrm{BOD}_{5} /$ TKN ratio of leachate. The Pearson's product moment correlation coefficient $\left(r_{p}\right)$ was used as a measure of correlation in which the strength as well as direction of such a relationship is quantified. High $\mathrm{BOD}_{5} / \mathrm{TKN}$ ratios seemed to decrease the fraction of $\mathrm{AOB}$ population in the samples tested. The overall Pearson coefficient of -0.84 suggested that a moderate correlation exists between the $\mathrm{BOD}_{5} / \mathrm{TKN}$ ratio and fraction of amoA gene (determined at $95 \%$ confidence interval). On the other hand, there was a complete absence of correlation between the TKN concentration and amo $A$ gene fraction $\left(r_{p}=-0,10\right)$, which indicates that the higher organic strength of leachate allows the heterotrophic bacteria to become dominant and does not allow for too much AOB proliferation. The effect of landfill age (which is indicated by $\mathrm{BOD}_{5} / \mathrm{COD}$ ratios) on the $a m o A$ fraction was not as apparent as changes in the $\mathrm{BOD}_{5} / \mathrm{TKN}$ ratio, as no significant correlation was found between $\mathrm{BOD}_{5} /$ COD ratios and amoA fractions $\left(\mathrm{r}_{\mathrm{p}}=-0,55\right)$. The only noticeable correlation is such that, at higher $\mathrm{BOD}_{5} /$ COD ratios (which indicate young landfill leachate) the fraction of ammonia-oxidizing bacteria is much lower (in the Antalya and Samsun samples).

Among the nitrite-oxidizing bacteria, Nitrospira gene copy numbers were consistently higher than those of Nitrobacter in all cases. Nitrobacter only accounted for $0.02 \%$ to $0.26 \%$ of the bacterial communities. The quantification results indicated that Nitrospira was the dominant NOB in all leachate samples. Consistent with previous studies [22, 39-40], the percentage of
Nitrospira biomass among all tested nitrogen converters was detected as the highest fraction. In the leachate sample taken from Bursa, this fraction was found to be $9.02 \%$, and such a high value means that Nitrospira is approximately 8 times more abundant with respect to average $a m o A$ fractions.

The literature includes limited studies attempting to understand the microbial transformations taking part in the nitrogen cycle in engineered and natural systems. The abundance of known contributors such as $\mathrm{AOB}$ and $\mathrm{NOB}$, and new players $\mathrm{AOA}$ and anammox were quantitatively analyzed at different environments using real-time PCR [22-23, 39-40]. In our previous studies, fractions of $\mathrm{AOB}, \mathrm{NOB}, \mathrm{AOA}$, and anammox among the total community were investigated in 3 full-scale wastewater treatment plants [39], in a pilot-scale membrane bioreactor (MBR) [40], and in a full-scale leachate treatment plant [22] using molecular microbiological tools like fluorescent in-situ hybridization (FISH), slot-blot hybridization, quantitative real-time PCR, and sequence analysis. These findings showed that Nitrosomonas and Nitrospira species were the driving ammonia- and nitrite-oxidizing bacteria, respectively. However, Nitrospira species were detected as approximately 5 times more abundant than AOB species in all samples. In parallel to our case, there are some studies in the literature trying to figure out why the nitrite-oxidizing bacteria outnumbered the ammonia-oxidizing bacteria [22, 32, 39-42]. For instance, Gieseke [41] used FISH to quantify nitrifying populations in a phosphateremoving biofilm and found that the abundance of the NOB population was detected as more than one order of magnitude higher than that of AOB. Similar to our study, Yao and Peng [43] investigated nitrification activities and microbial populations of ammoniumoxidizing bacteria and nitrite-oxidizing bacteria in 10 full-scale biological nutrient removal wastewater treatment plants in Xi'an, China. They found that the average percentage of $\mathrm{AOB}$ was $1.27 \%$ and that of NOB was $4.02 \%$. Using our previous experience with full-scale leachate and domestic wastewater treatment plants, we speculated that the high abundance of Nitrospira species may be due to alternative roles that they may have other than nitrite oxidation only [22, 33, 39-40]. The recent discovery of complete ammonia oxidizer (Comammox) organisms [18, 44-47], i.e., bacteria within the genus Nitrospira, which oxidize ammonia to nitrate completely in one step, can be an answer to how such a high abundance is supported in natural and engineered systems. $\mathrm{Li}$ [46] investigated the pathways of nitrogen $(\mathrm{N})$ removal and $\mathrm{N}_{2} \mathrm{O}$ emission in a one-stage autotrophic nitrogen removal process under anaerobic conditions. They concluded that nitrogen converters were the dominant microbes, and were probably responsible for nitrogen removal under anaerobic conditions. Martinez [47] investigated the recent discovery of Nitrospira strains that can conduct complete ammonium oxidation. The phylogenetic 
analyses conducted in this study showed that just a few of the Nitrospira sequences found in the bioreactors were comammox. The higher abundance of the NOB population in previous works may point to the prominent contribution of Comammox in nitrate formation. However, further studies are needed to unveil to what extent these bacteria participate in nitrogen conversion inside landfills.

\section{Conclusions}

The molecular microbiological examinations using real-time PCR revealed that landfill leachate harboured microbial communities participating in nitrogen conversion, including ammonia- and nitriteoxidizing bacteria, ammonia-oxidizing archaea, and anammox bacteria. Nitrospira species were found to be present up to $9.02 \%$ among all microorganisms, which is the highest fraction in leachate samples tested. Nitrospira species are believed to have more roles than only nitrite oxidation. The presence of anammox bacteria and ammonia-oxidizing archaea revealed that partial nitrogen removal may occur inside the landfills. Therefore, the bio-augmentation potential of anammox may be promising for future studies when leachate is partially nitrified ex-situ in the case of mature landfills. The low percentage of AOA compared to the AOB suggested that bacteria rather than archaea drive nitrogen conversion in leachate samples. In this study, the effects of denitrification and dissimilatory nitrate reduction mechanisms were not taken into consideration.

\section{Acknowledgements}

The authors gratefully acknowledge financial support from Marmara University Scientific

Research Committee-BAPKO (project Nos. FEN-CDRP-110915-0435 and FEN-C-YLP-070617-0364).

\section{References}

1. CALLI B., MERTOGLU B., INANC B. Landfill leachate management in istanbul: Applications and alternatives. Chemosphere 59, 819, 2005.

2. AKGUL D., AKTAN C.K., YAPSAKLI K., MERTOGLU B. Treatment of landfill leachate using UASB-MBRSHARON-Anammox configuration. Biodegradation 24, 399, 2013.

3. SPAGNI A., PSAILA G., RIZZO A. Partial nitrification for nitrogen removal from sanitary landfill leachate. J Environ Sci Health A Tox Hazard Subst Environ Eng 49, 1331, 2014.

4. FERRAZ F.M., POVINELLI J., VIEIRA E.M. Ammonia removal from landfill leachate by air stripping and absorption. Environ Technol. 34, 2317, 2013.

5. HUANG H., XIAO D., ZHANG Q., DING L. Removal of ammonia from landfill leachate by struvite precipitation with the use of low-cost phosphate and magnesium sources. J Environ Manag, 145, 191, 2014.
6. FOO K., HAMEED B.H. An overview of landfill leachate treatment via activated carbon adsorption process. J Hazard Mater, 171, 54, 2009.

7. YE Z., WANG J., SUN L., ZHANG D., ZHANG H. Removal of ammonium from municipal landfill leachate using natural zeolites. Environ Technol, 36, 2919, 2015.

8. HALIM A.A., AZIZ H.A., JOHARI M.A.M., ARIFFIN K.S. Comparison study of ammonia and cod adsorption on zeolite, activated carbon and composite materials in landfill leachate treatment. Desalination 262, 31, 2010.

9. KRISTANTO G.A., RIALDI H., GUSNIANI I. Nitrogen Removal from landfill leachate via ex-situ nitrification and in-situ denitrification in laboratory scale bioreactor. Procedia Engineering 171, 425, 2017.

10. MERTOGLU B., CALLI B., INANC B., OZTURK I. Evaluation of in situ ammonia removal in an aerated landfill bioreactor. Process Biochem 41, 2359, 2006.

11. BERGE N.D., REINHART D.R., DIETZ J., TOWNSEND T. In situ ammonia removal in bioreactor landfill leachate. Waste Manage 26, 334, 2006.

12. SUN X., ZHANG H., CHENG Z. Use of bioreactor landfill for nitrogen removal to enhance methane production through ex situ simultaneous nitrification-denitrification and in situ denitrification. Waste Manage 66, 97, 2017.

13. CHUNG J., KIM S., BAEK S., LEE N.H., PARK S., LEE J., LEE H., BAE W. Acceleration of aged-landfill stabilization by combining partial nitrification and leachate recirculation: A field-scale study. J Hazard Mater 285, 436, 2015.

14. HAO Y.J., JI M., CHEN Y.X., WU W.X., HAO Y.J., ZHANG S.G., LIU H.Q. The pathway of in-situ ammonium removal from aerated municipal solid waste bioreactor: Nitrification/denitrification or air stripping? Waste Manage Res 28, 1057, 2010.

15. THAMDRUP, B. New pathways and processes in the global nitrogen cycle. Annu. Rev. Ecol. Evol. Syst. 43, 407, 2012.

16. WU F., WANG W., FENG H., GU J.D. More wide occurrence and dominance of ammonia-oxidizing archaea than bacteria at three Angkor sandstone temples of Bayon, Phnom Krom and Wat Athvea in Cambodia. Int Biodeterior Biodegradation 117, 128, 2017.

17. JETTEN M.S.M., STROUS M., VAN DE PASSCHOONEN K.T., SCHALK J., VAN DONGEN U.G.J.M., VAN DE GRAAF A.A., LOGEMANN S., MUYZER G., VAN LOOSDRECHT M.C.M., KUENEN J.G. The anaerobic oxidation of ammonium. Fems Microbiol Rev 22, 421, 1998.

18. DAIMS H., LEBEDEVA E.V., PJEVAC P., HAN P., HERBOLD C., ALBERTSEN M., JEHMLICH N., PALATINSZKY M., VIERHEILIG J., BULAEV A., KIRKEGAARD R.H., VON BERGEN M., RATTEI T., BENDINGER B., NIELSEN P.H., WAGNER M. Complete nitrification by nitrospira bacteria. Nature $\mathbf{5 2 8}$, 504, 2015.

19. MUNZ G., SZOKE N., OLESZKIEWICZ J.A. Effect of ammonia oxidizing bacteria (AOB) kinetics on bioaugmentation. Bioresource Technol 125, 88, 2012.

20. BOOTHE D.D.H., SMITH M.C., GATTIE D.K., DAS K.C. Characterization of microbial populations in landfill leachate and bulk samples during aerobic bioreduction. Adv Environ Res 5, 285, 2001.

21. MERTOGLU B., SEMERCI N., GULER N., CALLI B., CECEN F., SAATC A.M. Monitoring of population shifts in an enriched nitrifying system under gradually increased cadmium loading. J Hazard Mater 160, 495, 2008. 
22. YAPSAKLI K., ALIYAZICIOGLU C., MERTOGLU B. Identification and quantitative evaluation of nitrogenconverting organisms in a full-scale leachate treatment plant. J Environ Manage 92, 714, 2011.

23. GEETS J., DE COOMAN M., WITTEBOLLE L., HEYLEN K., VANPARYS B., DE VOS P., VERSTRAETE W., BOON N. Real-time pcr assay for the simultaneous quantification of nitrifying and denitrifying bacteria in activated sludge. Appl Microbiol Biot 75, 211, 2007.

24. SMITH C., BERG D., BEAUMONT S., STANDLEY N.T., WELLS D.N., PFEFFER P.L. Simultaneous gene quantitation of multiple genes in individual bovine nuclear transfer blastocysts. Reproduction 133, 231, 2007.

25. EHRIG H.J. Quality and quantity of sanitary landfill leachate. Waste Manage Res 1, 53, 1983.

26. HUANG W., WANG Z., GUO Q., WANG H., ZHOU Y., NG W.J. Pilot-scale landfill with leachate recirculation for enhanced stabilization, Biochem. Eng. J. 105, 437, 2016.

27. KULIKOWSKA D., KLIMIUK E. The effect of landfill age on municipal leachate composition. Bioresource Technol 99, 5981, 2008.

28. TIMUR H., OZTURK I. Anaerobic sequencing batch reactor treatment of landfill leachate. Water Res 33, 3225, 1999.

29. BOVE D., MERELLO S., FRUMENTO D., ARNI S.A., ALIAKBARIAN B., CONVERTI A. A critical review of biological processes and technologies for landfill leachate treatment. Chem Eng Technol 38, 2115, 2015.

30. GARBARRO' J., GANIGUE' R., GICH F., RUSCALLEDA M., BALAGUER M.D., COLPRIM J. Effect of temperature on AOB activity of a partial nitritation SBR treating landfill leachate with extremely high nitrogen concentration. Bioresource Technol 126, 283, 2012.

31. FERNANDES H., VIANCELLI A., MARTINS C.L., ANTONIO R.V., COSTA R.H.R. Microbial and chemical profile of a ponds system for the treatment of landfill leachate. Waste Manage 33, 2123, 2013.

32. STAMPS B.W., LYLES C.N., SUFLITA J.M., MASONER J.R., COZZARELLI I.M., KOLPIN D.W., STEVENSON B.S. Municipal solid waste landfills harbor distinct microbiomes. Front Microbiol 7, 534, 2016.

33. HARMS G., LAYTON A.C., DIONISI H.M., GREGORY I.R., GARRETT V.M., HAWKINS S.A., ROBINSON K.G., SAYLER G.S. Real-time PCR quantification of nitrifying bacteria in a municipal wastewater treatment plant. Environ Sci Technol 37, 343, 2003.

34. JUNG M.Y., PARK S.J., MIN D., KIM J.S., RIJPSTRA W.I.C., DAMSTE J.S.S., KIM G.J., MADSEN E.L., RHEE S.K. Enrichment and characterization of an autotrophic ammonia-oxidizing archaeon of mesophilic crenarchaeal group i.1a from an agricultural soil. Appl Environ Microb 77, 8635, 2011.
35. PARK B.J., PARK S.J., YOON D.N., SCHOUTEN S., DAMSTE J.S.S., RHEE S.K. Cultivation of autotrophic ammonia-oxidizing archaea from marine sediments in coculture with sulfur-oxidizing bacteria. Appl Environ Microb 76, 7575, 2010.

36. ZHANG D., VAHALA R., WANG Y., SMETS B.F. Microbes in biological processes for municipal landfill leachate treatment: Community, function and interaction. Int. Biodeterior. Biodegradation 113, 88, 2016.

37. LIMPIYAKORN T., FURHACKER M., HABERL R., CHODANON T., SRITHEP P., SONTHIPHAND P. Amoaencoding archaea in wastewater treatment plants: A review. Appl Microbiol Biot 97, 1425, 2013.

38. WANG C., ZHAO Y., XIE B., PENG Q., HASSAN M., WANG X. Nitrogen removal pathway of anaerobic ammonium oxidation in on-site aged refuse bioreactor. Bioresource Technol 159, 266, 2014.

39. YAPSAKLI K. Co-occurrence of nitrogen-converting organisms in full-scale treatment plants. J Environ Sci Heal A 45, 1060, 2010

40. OZDEMIR B., MERTOGLU B., YAPSAKLI K., ALIYAZICIOGLU C., SAATCI A., YENIGUN O. Investigation of nitrogen converters in membrane bioreactor. J Environ Sci Heal A 46, 500, 2011.

41. GIESEKE A., PURKHOLD U., WAGNER M., AMANN R., SCHRAMM A. Community structure and activity dynamics of nitrifying bacteria in a phosphate-removing biofilm. Appl. Environ. Microbiol 67, 1351, 2001.

42. HATZENPICHLER R. Diversity, physiology, and niche differentiation of ammonia-oxidizing archaea. Appl. Environ. Microbiol. 78, 7501, 2012.

43. YAO Q., PENG D.C. Nitrite oxidizing bacteria (NOB) dominating in nitrifying community in full-scale biological nutrient removal wastewater treatment plants. AMB Express. 7, 25, 2017

44. VAN KESSEL M.A.H.J., SPETH D.R., ALBERTSEN M., NIELSEN P.H., OP DEN CAMP H.J.M., KARTAL B., JETTEN M.S.M., LUCKER S. Complete nitrification by a single microorganism. Nature 528, 555, 2015.

45. WANG Y., MA L., MAO Y., JIANG X., XIA Y., YU K., LI B., ZHANG T. Comammox in drinking water systems. Water Res. 116, 332, 2017.

46. LI K., FANG F., WANG H., WANG C., CHEN Y., GUO J., WANG X., JIANG F. Pathways of $\mathrm{N}$ removal and $\mathrm{N}_{2} \mathrm{O}$ emission from a one-stage autotrophic $\mathrm{N}$ removal process under anaerobic conditions. Sci Rep. 7, 42072, 2017.

47. MARTINEZ A.G., SANCHEZ A.R., VAN LOOSDRECHT M.C.M., LOPEZ J.G., VAHALA R. Detection of comammox bacteria in full-scale wastewater treatment bioreactors using tag-454-pyrosequencing. Environ Sci Pollut Res. 24, 25501, 2016. 